\title{
Language Used in Social Media and Its Impact Toward Teens Language Acquisition
}

\author{
$1^{\text {st }}$ Ahmad 'Ali Maghfur' 1 , $2^{\text {nd }}$ Masruhan $^{1}, 3^{\text {rd }}$ Rohmani Nur Indah ${ }^{1}$ \\ \{ibrahimmaghfur@gmail.com ${ }^{1}$, masruhan920@gmail.com ${ }^{1}$, masruhan920@gmail.com ${ }^{1}$ \} \\ Universitas Islam Negeri Maulana Malik Ibrahim, Malang, Indonesia ${ }^{1}$
}

\begin{abstract}
The development of technology in the modern era today is so fast and easy to use for the general public, including the information spread through gadgets. Such internet-connected technology makes it easy for users to access information around the world through the most common application for teenagers namely social media. This application is easy to obtain and use, as well as expand the network of teenagers to access information that is educative, recreational and social. This paper discusses the use of social media and its impact on language acquisition in adolescents. The method of data collection uses observation and interviews with students of MTs Negeri Batu, Indonesia. The study results show that the use of social media does not fully have a positive impact on the acquisition of language in adolescents. This research is expected to be a consideration for educators and parents to monitor the use of social media applications for children to contribute more positively.
\end{abstract}

Keywords: language acquisition; social media; teens language

\section{Introduction}

Human need for information and news is one of the things that cannot be left behind, from state news, crimes, gossip, and other news that is considered entertaining, can fill the void of time or fulfill curiosity. Along with the development of media technology that contains news not only displayed in print versions such as newspapers and magazines, but many online media that facilitate access to information to get interesting news. Online access is more practical, instant and inexpensive.

One online media that offers practical and instant interesting news is social media where users can participate in creating content such as blogs and other social networks. This media is easy to use and portable so users can always access the latest information while participating through a network of messages and comments. This is what maximizes the use of social media to express or express various things, including ideas, moods and the likeness of its users.

It cannot be denied that the benefits of social media can dominate various communication and interaction activities that require quick and new access. Access to this fast communication on the one hand helps users from both adults and adolescents. But on the other hand it also raises the phenomenon of language summarization used in communicating through social media. Not infrequently social media users especially teenagers abbreviate words or sentences written, such as writing the word "makan" to "mkn", "gede rasa" to "GR". These abbreviations are not listed in the Indonesian Language Dictionary, which can be categorized in language 
creativity but does not always facilitate the reader. In addition to communicating on social media, teenagers often use slang language which they think is the language of young people.

Teenagers are young people who have different characters from the previous generation, namely childhood and after that is adulthood. In the group of adolescents there are individuals who have similarities in age range, and experience important historical events in the same time period [1]. The criteria for language diversity in individual adolescents used in social media are the focus of this study. This is because adolescents, especially the $\mathrm{Z}$ generation, have the following characteristics: (1) fluent technology, thirst for technological renewal and highly adaptable to technological applications, (2) social, very intense interacting through social media with all circles, (3) expressive, tend to be tolerant with cultural differences and very concerned about the environment, and (4) quickly move from one thought / job to another thought / work [2].

For teenagers online social media is the main tool for networking especially when puberty the need to communicate with the opposite sex is felt to be most effective through cyberspace. The awkwardness of speaking, speaking and communicating with the opposite sex immediately decreases if it is assisted by social media which is equipped with various features such as photos, videos or emoticons [3].

A variety of language phenomena in the use of social media by teenagers requires further exploration. By conducting a study on the use of social media by adolescents, a description of the language patterns in adolescent social media will be obtained and how they will impact on language acquisition. The focus of this research study is to describe the impact of social media use on language acquisition in adolescents.

\section{Literature Review}

\subsection{Social Media}

Social media is a group of internet-based applications built on various ideologies. Website technology has enabled the creation and exchange of content between social media users [4]. Online social media is used to share, participate and create content in blogs or social networks [5]. The variety of social media is always growing, but in Indonesia only a number of online social media are widely used such as Facebook, Twitter, Instagram, Watshapp, and Line.

Social media is accused of being able to damage communication ethics. Besides that the media can be used as a tool to drop the image of a person or group with hoax news and inappropriate words [6]. On the other hand, social media also has two sides, positive and negative. The positive side is to make it easier for children to access schoolwork materials, find lecture materials, and expand networks of friends. The negative side is the lack of a child's social spirit towards the environment and people around. Children will be too cool with the social media world, become lazy and wasteful [7].

Social media for adolescents is often called complement to face-to-face interaction [8]. Because of that, in addition to friendship in real terms, social networking in cyberspace becomes a need for social media users, especially among teenagers. Social media for American teenagers is said to have more positive contributions because it is considered to facilitate interaction in choosing, adding or removing friends. In addition, social media makes it easy for teenagers to express freely in expressing their feelings. Directly or indirectly the ease of expression also reduces stress levels in adolescents. In addition, by expanding information networks can free teenagers from feeling bored [9]. 
Social media is not only intended for certain groups who utilize information technology in gaining popularity. Teenagers who have an introverted personality in their daily lives, can in cyberspace represent themselves as celebrities through social media [10].

\subsection{Language acquisition}

Language acquisition is the process of the child's brain in acquiring his mother tongue or first language. One of the stages of obtaining language is how from a baby, the child gets his mother's language stimuli unconsciously or there is no element of intentional learning of mother tongue [11]. Language acquisition differs from language learning. If language learning is a process that takes place when the child learns a second language after acquiring mother tongue. So the conclusion is that language acquisition is related to mother tongue or first language, while language learning is related to second language [12].

In the acquisition of language there are two categories, namely the acquisition of language that is sudden, sudden and unconscious, this acquisition is called the competency process. Second, language acquisition is gradual which grows from pralinguistic social, and cognitive achievement. This category is called the performance process. Although the competency process is brought from birth, but children still need guidance that will bring performance in language [12].

Language acquisition can be obtained from all activities, experiences, and the environment, so that it is very possible for language acquisition to take place through the social media used. Languages in social media can affect the language that has been obtained before. As for adolescents, the process of language acquisition does not take place naturally as fast as the golden age of childhood brain development. This is because at puberty it has reached lateralization maturation levels which impact from cognitive maturation [13]. Thus in this period adolescents apply the most complex linguistic results, namely pragmatic acquisition.

\section{Methods}

This research was conducted with a qualitative design to develop an understanding of the phenomenon of social media use and its impact on language acquisition in adolescents. Descriptive method was chosen because this study presented reality objectively in accordance with the context encountered, namely about the use of language in social media. This study intends to describe the facts or phenomena of language use in the form of words or sentences in the context of written and oral social media users from among teenagers.

The data in this study are written data from the renewal of status and comments by adolescents who actively use online social media whose data is obtained from observations. In addition, the techniques used to collect data are interviews with teenage subjects. The selected subjects are students of MTs Negeri Batu, Indonesia. Selection of subjects in the category of adolescents aged 12-13 years, actively using social media accounts every day, and having more than one social media account. As for studying this phenomenon, psycholinguistic theories of language acquisition are used [12].

\section{Findings and Discussion}


The first research subject, AM other than schools in MTs also lived in Islamic boarding schools. In everyday life it still takes time to communicate via social media. One of the statuses taken randomly from their social media accounts is:

"Alhamdulillah Bsok Otewe k bali semga bisa jadi momen terindh" dan "ikut manteman bli oleh2 jg ikut senang sekaleee”.

AM expressed his excitement to take a trip to Bali. In the expression of gratitude AM uses standard writing, but when stating the news the expression used emphasizes his identity as a teenager by abbreviating Bsk, semga, terind, bli, jg. The slang character appears in the words Otewe, manteman and sekaleee.

In the interview, the spoken language used by AM also shows the character of his identity. To answer one of the questions given about when the subject will return home, AM responds:

"Yaa... saya sih kalau pondok sudah libur juga langsung capcuss mas... iya gak bro" (while glancing at his friend).

In the utterance the word capcuss which means to go and bro which is commonly used as a friend, is this slang word that characterizes the subject's identity as a teenager who follows the present vocabulary variant. AM uses the greeting in responding to show the position of the younger speaker. AM also emphasized his character as a teenager who was the same age as when he confirmed with his friend, bro. Both written and oral phrases AM consistently characterizes the identities of speakers as teenagers who have high social networks represented by friends and bro.

In the second subject, AN represents students who live with family at home. The use of social media is more free because it is not limited to time after school hours. From the wrong status of a social media account taken randomly, AN wrote:

"Njiiiirr jam segini baru pulang".

In this status the subject expresses his feelings towards the current situation he experienced. There is the word slang "njiiiirr" as an expression of surprise or disappointment.

In the interview, AN answered questions about activities carried out after school with the following responses:

"rehat mas, eh maem dulu ding... abis itu rehat mas"

AN's speech has a similar pattern with its status which is concise and direct at its core. In responding to $\mathrm{AN}$, it shows the identity as a child or speaker who is younger than the interlocutor with the greeting, and characterizes the cultural background of the choice of the word maem, ding. Subjects make corrections with utterances eh, ding. The rest break repetition clarifies the character who speaks directly to the point.

The third subject, the US has in common with the second subject who daily lives at home with family. On one of the status of his social media accounts, the subject writes:

"Ow em ji ... suka suka suka deh bonekanya"

At this status the expression of excitement on an object is shown from repetition like to like. The US also characterizes its teenage identities from its preferred object, namely dolls. In addition, teenage characters also appear from the expression ow em ji or Oh My God.

In answering questions about what activities the subject has attended in school lately, the US responds:

"Paskibra mas... tapi kadang bikin mager soalnya kakak kelas ada yang rese... bikin bete mas"

US response also shows the position of younger speakers with the word greeting mas. Not unlike the writing characters, in the US oral response also put forward the outpouring of feelings. If the writing about feelings of love in the US oral context reveals feelings of 
annoyance with the word mager means lazy to move. Besides that, the US said that receipt meant annoying. The US also said that it means boring today or bored. Using a variety of words slang mager, rese, really shows the characterization of the identity of speakers as teenagers who follow the present variant of vocabulary.

The fourth subject, NM represents youth intra-school organizational activists. On one of the randomly selected social media account status, NM wrote:

"jadi orang kok ember banget si....huh"

The word ember means not be able to keep secrets or talk too much that should not. This status represents his opinion to someone who is not in accordance with the standards he considers better.

From the interview process, responses were obtained to the questions about the reasons why subjects chose to attend MTs. NM answered as follows:

"Secara gitu mas.... wong teman saya kebanyakan sekolah disini juga kok."

NM response has a similar pattern with the written language which is characterized as concise and direct at its core. In oral speech, the identity as a teenager is shown by the use of the word slang as an insertion of sentences that cannot have direct meaning. In addition, the subject also uses the greeting to explain his position which is younger than the other person. Culture identity is also raised from the word wong meaning because.

From the pattern of language on the status of social media and speech in the response of research subjects, there is a similarity in the representation of identity as a teenager characterized by several linguistic markers. First, the use of concise and directive sentences is at its core. This is in accordance with the expressive characteristics of netizens so that they do not like long expressions, long-winded, small talk or not directly targeting the point. Second, the use of slang language that has been attached to every adolescent utterance, such as the word otewe, ow em ji, mager, bete, on, rese, and bucket are the characteristics of netizens' social nature.

Affirmation of adolescent character that is slang and follows the update of current vocabulary shows the breadth of online social networks that he has. Third, the consistency of speech patterns on status and interviews also indicates the use of language interference, namely the tendency to accustom the pronunciation of a language to other languages whether it be vocabulary or grammar [14]. In this case the subject places the interlocutor as an equivalent persona, so tends to choose slang. Whereas in the rules that should be slang language is not used in the context of talking to strangers or new conversational partners. Generally the style of formal language will be chosen.

Shortening of words / sentences or the use of slang words used in social media has become a separate language for teenagers, in the end the use of words / sentences is used in communicating daily in the school or outside the school. Adolescents consider the abbreviated language available in social media to be an affirmation of their identity as a teenager who usually uses slang language [15].

The assertion of identitias as adolescent speakers causes reluctance to use formal language that is context-appropriate. The tendency to abandon standards is also more prevalent in the English context in America. Even though the use of non-standard language creates the impression of being ridiculous, lazy, educated, but this trend is even more prominent on online social media. Diachronic studies of language observations on American teen social media show that the tendency to leave standard language indirectly has a broad impact on the linguistic system [16].

If the consistency of the use of slang for various speech contexts is left continuously, it does not rule out the emergence of demotivation to develop the use of standard language. This 
phenomenon is also found among Swedish teenagers, making it difficult for teachers in the process of developing written and speech skills in the academic context [17].

The use of social media apparently is oriented for peer socializing but did not appeat to voluntarily or independently integrate into learning as well as contributing to the language of teen [18]. However, if used in such a way as to implement a good strategy, the concern that social media does not support teenagers' academic progress will be eliminated. Social media such as Facebook, Edmodo, Canvas, Blackboard and other applications can be used to support the learning process by optimizing available networking features [19].

\section{Conclusion}

Based on the findings of this study, it can be concluded that the use of social media does not fully have a positive impact as stated in other studies, especially when viewed in terms of language acquisition in adolescents. The use of language in adolescents both in the status of social media and oral context shows the tendency of pragmatic consistency that does not heed the differentiation of language rules based on context. In addition, the use of social media has affected the interaction among teens compared to their real life interaction [20], therefore it strengthens the assumption that the language use in social media resembles that in real life context.

Social media gives users or netizens access to emphasize the identity as an expressive Z generation characterized by linguistic markers in the form of concise utterances, directive and direct to the core, and social $\mathrm{Z}$ generation that sets word choices according to slang. However, the limitations of cyberspace cause limitations in pragmatic acquisition so that the research subject cannot distinguish the context of speech so that it does not consider the speech rules according to context. This is the reason why it is necessary to monitor the use of social media for teenagers to balance their linguistic input so that it is adequate for the pragmatic acquisition process.

Acknowledgements. This paper in conjuction with The 1st Annual International Conference on Language, Literature and Media (AICoLLiM 2018) in Malang, East Java.

\section{References}

[1] M. Corste "The time of generations" Time \& Society vol. 8 no. 1, 2012, pp. 249-272.

[2] Y. S. Putra "Theoretical review: teori perbedaan generasi" Among Makarti vol. 9 no. 18, 2016, pp. 123-134.

[3] D. E. Howard, K. J. Debnam \& A. Strausser "I'm a stalker and proud of it": Adolescent girls' perceptions of the mixed utilities associated with internet and social networking use in their dating relationships. Youth and Society https://doi.org/10.1177/0044118X17716948. 2017.

[4] A. M. H. Kaplan, "Users of the world, unite! the challenges and opportunities of social media" Busines Horizons vol. 53 no.2 2010, pp. 59-68.

[5] A. S. Cahyono "Pengaruh media sosial terhadap perubahan sosial masyarakat di Indonesia" Publiciana vol. 9 no.1, 2016, pp. 140-157.

[6] N. Y Vera "Media sosial dan runtuhnya etika komunikasi: studi kasus akun Facebook Quraish Shihab dan Anies Sandy" Prosiding seminar nasional komunikasi, 2016, pp. 198-205. 
[7] S. Fitri "Dampak positif dan negatif sosial media terhadap perubahan sosial anak" Naturalistic vol. 1 no. 2, 2017, pp.118-123.

[8] R. N. Indah \& N. F. Rifana "The pattern of compliments in Instagram photo comments" International Journal of Research Studies in Language Learning, vol.7 no. 3, 2017, pp. 57-69.

[9] E. Weinstein “ The social media see-saw: Positive and negative influences on adolescents' affective well-being” New Media and Society https://doi.org/10.1177/1461444818755634. 2018.

[10] A. Marwick \& D. Boyd "To see and be seen: Celebrity practice on Twitter" Convergence vol.17 no.2, 200, pp. 139-158.

[11] D. Prasetiawan "Pemerolehan bahasa pada anak suku Sasak dalam perspektif Psikolinguistik" Jurnal Pendidikan Bahasa dan Sastra vol. 17 no.1, 2017, pp. 72-80.

[12] A. Chaer Psikolinguistik : kajian teoritik. Jakarta: Rineka Cipta 2003.

[13] R. N. Indah. \& Abdurrahman Psikolinguistik: konsep \& isu umum. Malang: UIN Press. 2008.

[14] A. Dimyati, A. Muhadhoroh Fi Ilmi al Ijtima'iyah. Surabaya: Mathba' Dar al-Ilm alLughowiyah 2010.

[15] E. Swandy "Bahasa gaul remaja dalam media sosial Facebook" Bastra vol. 1 no.4, 2017, pp.119.

[16] S.A. Tagliamonte "Teen talk: The language of adolescents" Language in Society vol. 46 no. 5 2017, pp. 742-745.

[17] P. Sundqvist "Classroom vs. extramural English: Teachers dealing with demotivation" Language and Lingusitics Compass vol. 7 no. 6, 2013, pp.329-338.

[18] J. Li, C. Snow, \& C. White "Teen culture, technology and literacy instruction: urban adolescent students' perspectives" Canadian Journal of Learning and Technology vol. 41 no. 3 2015, pp. 1-36.

[19] L. Nielsen "Using social media to engage students and families" Educational Horizons vol. 92 no. 2, 2013, pp.16-20.

[20] G.O. Okafor \& C.A. "Social Media Use And Real-life Social Relationships" Okoye Creative Artist: A Journal of Theatre and Media Studies vol. 8, no. 2 2014, pp. 1-14. 